\title{
LACKLUSTRE OFFERING PLATES? SYMBOLIC FOOD CONSUMPTION, RITUAL AND REPRESENTATIONS IN ANCIENT EGYPTIAN FUNERARY CULTURE
}

Katharina Zinn

\author{
$N$ [the deceased name to be included] shall not be hungry, \\ he shall not be thirsty, for Ha has saved him and removed \\ his hunger, and hearts are filled, are filled. \\ O you who are in charge of food and attend to supplies of \\ drink, $N$ is commended to the House of Bread...Re himself \\ commended him; Re commends him to those who are in \\ charge of food supplies for this year.
}

(Book of the Dead 178; Faulkner and Andrews 1998, 131)

\section{INTRODUCTION}

This paper will analyze a seemingly lacklustre object which nevertheless materializes a wide array of concepts inherent to the funerary beliefs of the ancient Egyptians: the miniature offering plate or dish CC308.004 (Fig. 11.1). This particular miniature pottery vessel is one of a number of objects from the Egyptian collection at Cyfarthfa Castle Museums and Art Gallery, Merthyr Tydfil, Wales. ${ }^{1}$

\section{$<$ FIGURE 11.1 here $>$}

Miniature vessels were used as votive offerings throughout Egyptian pharaonic history from the earliest times onward. The specific forms chosen for such miniatures seem to reference vessel types typical for the Predynastic and Early Dynastic periods (Allen 2006, 19). The form of these vessels can range from dishes, pots to bottles and jars. Dishes such as CC308.004 were put in tombs (Hayes 1978, 118; Richards 2005, 162, fig. 75) or formed part of foundation deposits (Weinstein 2001, 559; BM EA64088; MfA 05.62). 
Like many museum objects which entered collections during the $19^{\text {th }}$ and early $20^{\text {th }}$ centuries, this object has no firm provenance. Its date of manufacture and its use are unknown (infra). Nevertheless, the aim of the current study is to discuss the Sitz im Leben (place in life) this object might have had in ancient Egypt. In particular I will explore what it might tell us about the (im)materiality of foodstuffs in ancient Egypt. Specifically, I will examine aspects of symbolic food consumption and ritualistic offering, both of which were important aspects of ancient Egyptian funerary culture. In this context, miniature vessels played an important role irrespective of whether they contained actual food or not. They connect the materiality of food - or the non-materiality in case actual food was absent - with society and the social / collective memory; the simple offering dish becomes a symbol for the (non-)materiality and beliefs of the ancient Egyptian funerary sphere.

Food played an important part during a person's lifetime - as is illustrated, for example, by the records of rations of bread and beer (cf. Ryan this volume) - and it was an equally important concern for the afterlife as well. The narrative which can be constructed around CC308.004 will encompass both spheres and will enable us to explain the potential Sitz im Leben of this miniature bowl. Situating CC308.004 within its funerary context will contribute to the archaeology of food studies which often focuses on the actual remains of foodstuffs while leaving symbolic consumption largely out of the discussion (Samuel 2006; Samuel 1999, 122-5).

\section{308.004 - WHAT ARE YOU?}

'Matter represents, but it does not do so in an arbitrary manner. Symbols and symbolic system do not draw randomly on the material world to create, define and express themselves, as though they constituted a divine font of self-creation.'

(Boivin 2008, 81).

Following this premise, I wish to explore the materiality and symbolic representation of the material artefact CC 308.004 as well as the engagement between the object and its users. The object in question is an example of a red coarse ware pottery bowl made from Nile silt. It measures $5 \mathrm{~cm}$ in diameter and is $1.4 \mathrm{~cm}$ high. The clay was completely fired through, leaving 
no black core in the fabric, as was so often the case. The original colour of the clay ranges from grey to black, the reddish colour of Nile silt ware is the result of the firing process (Bourriau et al. 2000, 121). When fired in less controlled conditions such as open 'bonfire' firing, the core is not properly fired and retains a greyish/blackish layer inside (Bourriau et al. 2000, 127). The miniature bowl does not show any sign of having been slipped.

The sphere dish is hand moulded with a level base (Fig. 11.2) and a flared pointed - or unmodelled - rim (Wodzińska 2010, 1-16). The base is not completely flat; hence the dish teeters on an even surface. It is well preserved, except for some areas of the rim which are broken away. The damage very likely occurred (much) before the time of acquisition at the beginning of the twentieth century AD. The breaks reveal the coarseness of the material (Fig. 11.3). A comparable but undamaged and slightly earlier exemplar comes from the secured archaeological context of Giza Mastaba G 7000 X, excavated by the Harvard University Museum of Fine Arts Expedition in 1926 (MfA 05.62). The model bowl MfA 05.62 is somewhat larger but similar in colour and fabric. Pending further investigation of CC 308.004 with a high-resolution microscope, the visual classification of the Nile fabric can be very preliminarily assigned to Nile C (for the Vienna System see Arnold and Bourriau 1993, 173-4; Bourriau et al. 2000, 131). Owing to the relatively fine structure of the silty clay, a categorisation under Nile $\mathrm{B}_{2}$ could also be considered, especially as it is difficult to draw a clear line between Nile $B_{2}$ and C without closer examination (Arnold and Bourriau 1993, 172).

<FIGURE 11.2 and 11.3 here>

The visual characteristics of the material and shape therefore suggest a very simplistic 'lacklustre' or mundane - object. Nonetheless, it is striking that a more tactile hands-on examination suggests a design aspect - the artefact's shape follows smoothly the contours of the hand. This may suggest, first, that the fact that it teeters on a flat surface is not necessarily a sign of bad quality. Second, it may suggest that it was held in the hand during a ritual act before it was finally placed down on a sandy surface.

Comparative examples have been found all over Egypt and dated to different time periods: for example, object MMA 13.183.185 from the tomb of Perneb at Saqqara, Old Kingdom, 
Fifth Dynasty (MMA 13.183.185; Hayes 1978, 91) is similar to BM 1888,0601.735.b, found at Naukratis in the Delta and dated to the Late Period (BM 1888,0601.735.b). They could vary in shape and size, as shown by other vessels also found in the tomb of Perneb (MMA 13.183.189, MMA 13.183.190 or MMA 13.183.187), but all fulfilled the same function. We also see similar shapes in stone. An example is the calcite dish from Saqqara (BM EA67299) which belongs to the same dynasty as the pottery dishes from the tomb of Perneb. Others were made from limestone (Hayes 1978, 118-19, fig. 72).

This random sample conforms to the observation made by Susan Allen that such miniature vessels seem to have developed from types used in the late Predynastic and Early Dynastic periods, and that this object type persisted in use due to its symbolic connotations and use within ritual practice. Pottery seriation, local and regional stylistic developments, did not influence these forms, whether made from pottery, stone or metal (Allen 2006, 19). As discussed above, such objects might come from tomb contexts, appear in foundation deposits or otherwise be connected with pilgrimage sites (especially Abydos). Whatever their context of use, however, these miniature bowls all share the same aspect of being votive and incorporated within a ritual. For this chapter, however, I will focus specifically on the funerary sphere.

\section{ANCIENT EGYPTIAN FUNERARY BELIEFS - THE BACKGROUND}

\section{Death as a Rite of Passage}

Death, and the transition to whatever will come, is one of the most profound rites of passage: the change from this life to the next, eternal form of life covers all three stages (van Gennep [1909] 1960; Davies 1994, 1): the pre-liminal (separation), liminal (transition) and postliminal (incorporation) stage. In ancient Egypt, these stages were understood, re-enacted and remembered as cyclical events, as recurrent interactions with the dead and the cult for the ancestors (Harrington 2013, especially 13, fig. 30). People envisaged the afterlife as a continuation of their existence before death, but in an ideal setting. Crossing the boundaries between this mortal world and the afterlife also involved acquiring a certain level of divinity (Taylor 2001, 31-2; Pinch 2006, 147). 
Death as rite of passage is mostly discussed in connection with the liminal stage (Yeoh 1999, 241), the transition between this life and the afterlife. This focus on transition seems to be suggested by the funerary text corpus of the New Kingdom, the Book of the Dead. Spell 170 explains death as 'the night of going forth to live' (Te Velde 1967, 6). ${ }^{2}$ However, ideas concerning the other two stages, separation and incorporation, are equally important within the system of ancient Egyptian funerary beliefs. Death was seen as the transition into a new phase or cycle of life - the eternal afterlife - and as such discussed as rebirth. Understood in this way, one rite of passage is connected with another: death is linked to the liminal process of pregnancy and birth (Frood 2010,480). In this sense, the human sequence of birth - life death is part of an overall recurring cycle of creation; all three stages as described in the rites of passage approach repeat themselves indefinitely and should be seen as continuous change (Taylor 2001, 12). Especially from the New Kingdom onwards, the survival and rebirth of the deceased is bound to the daily rebirth of the Sun God.

Similarly, the connection between the deceased and the living next of kin is clearly expressed in the morning scenes depicted in tombs (Kucharek 2005, especially 346-348). The depictions are mostly references to Isis and Nephtys mourning their brother Osiris. Some of the mourning scenes also offer a personalized connection between the living and their deceased relatives, as in the tomb of Ameneminet (TT 277; Osirisnet Ameneminet). However, rituals extended beyond the moment of the burial, allowing on the one hand for the deceased to be incorporated into a new social world, that of the afterlife, while on the other hand also enabling the bereaved to maintain a social memory, be it only for a few generations (Frood 2010, 488-9). These rituals invoked aspects of materiality that were crucial in magical contexts in which they appeared (infra).

Most of the material culture of ancient Egypt stems from the funerary sphere, being either connected to the tomb itself (tomb goods and painting / reliefs at the walls) or to the rituals evolving around the funerary sphere (mummification, Opening of the Mouth, funerary cult, ancestor cult etc.). This could be explained by the arid climate and the specific positioning of the tombs in the desert area, both of which reduced the danger of the objects being damaged by water; furthermore by the use of more durable materials or the ideal that tombs should be 
left untouched. Even so, these favourable conditions alone cannot fully explain the abundance of funerary goods, the richness of tomb art and architecture as well as the wealth of texts connected with death. These material manifestations also show the attitude the ancient Egyptians had towards the idea of death and resurrection as well as interpretations of life in general. In this sense, funerary remains have shaped our understanding of Egyptian society. In fact, material objects provide a way of communication with a distant civilization also by virtue of their materiality and their physicality. Artefacts do not need to be carrier of writing in order to convey important information, an insight a predominantly text-focussed Egyptological tradition often tends to forget. Moreover, in recent years Egyptology has become increasingly aware of the fact that a focus on elite funerary culture is insufficient to fill all gaps of knowledge and moreover creates a biased picture; one shaped towards the elite who could afford to leave these traces (Harrington 2013, IX; Taylor 2001, 7). It is often said that the Egyptians showed more care towards their afterlife than this life (Assmann 2005, 1620). That is not necessarily true. The deployment of material resources reflects different time frames: life in this world is limited in its temporal extension and thus represented by one life cycle; by contrast, life after death is covered by several recurring cycles that ideally last into all eternity. Therefore all provisions and equipment need to be tailored towards this duration.

As live is continuous and the afterlife seen as a variation of this life, e funerary beliefs and customs called for the preservation of the body. Objects placed in the tomb accompanied the person through all three liminal stages - separation, transition and incorporation. These objects were sometimes used, or at least commissioned, during a person's life, they not only surrounded the deceased in the transitional process but moreover served as tools to enable the transition before they were finally used in the afterlife to support and reaffirm the new, transformed version of life.

\section{Magic and the Funerary Sphere}

To the modern mind, magic often appears as opposite to religion or, at best, an early stage of religion (Ritner 2001, 321). Magic describes actions or knowledge relating to the supernatural or the demonic, but not the divine. The ancient Egyptians, however, did not perceive it as black art or sorcery, in conflict with religion (Ritner 1992, 189-92). Magic was inherent to 
overall Egyptian thinking and a regular part of religion at all levels of Egyptian society (Taylor 2001, 186), described as heka. This term defines a cosmic and divine power inherent to the universe. It could be personified as a male anthropomorphic god (Heka) who represented the tenth hour of the day and, as such, accompanied the Sun God in his day barque (Wilkinson 2003, 83, Te Velde 1970, Ritner 1993, 14-28). Both the concept heka and the deity Heka are attested from the Old Kingdom up to the Coptic Period, with the earliest mention of the god in the funerary temple of Sahure (Fifth Dynasty), and both are named in the Pyramid Texts (spells 472 and 539).

Magic, as empowering potency, existed from the first moments of creation. It was conceived by the creator god's heart at the beginning of time enabling him to start the creation process (Ritner 1992, 192). Heka appeared even before the creative word $H u$, the first creation of ReAtum, the creator god; therefore magic was already in the world when the gods and the cosmos were shaped. This primordial aspect is stressed in the Coffin Text spell 648 (Ritner 1993, 17).

Based on ancient Egyptian perception, magic was generally understood as being amoral and not immoral, as it is often seen today. Magic in ancient Egypt covered both sides of what we would describe today as white and black magic (Baines 2006, 1). Therefore, heka was also understood as having latent destructive potential, as presented in the paragraphs 165-174 of the medical Pap. Ebers. Here it is said that it is necessary to drive heka out of the bodies of patients in order to allow them to recover. Even gods might feel threatened by the mighty power of heka as described in papyrus Berlin 3048, 11.8-9: 'Everybody shakes when his [ie. the creator's] ba comes into being, heka, who has power over the gods' (Zinn 2013, 4227). The $b a$ is one of the constituent elements of human and divine beings, often imperfectly translated as 'soul' or 'personality', mainly active in the afterlife (Taylor 2001, 20-3; Assmann 2005, 90-6). Because of his potency, heka is able to protect Osiris in the underworld and therefore played an active (religious) role in the afterlife. Working on the associative principle of magic, the artefacts placed in the tomb utilized the associative symbolic power of objects; they were seen as equal. In this way for example, water poured from a libation dish (First Dynasty; MMA 19.2.16) in the shape of the hieroglyphs ankh (life) and $k a$ (life-force) absorbs the power of life from the symbols on it and presents it to the $k a$, 
another constituent element of the person of the deceased (Taylor 2001, 18-20; Assmann 2005, 96-102).

Magic was integrated into all aspects of Egyptian life and was used by members of all classes of society. It was connected with myth, used by demons and spirits as well as employed by magicians and priests in written form, in the same way as the use of magical techniques, magic figurines, statues and amulets. Amulets and jewellery made in the shape of, or bearing amuletic features, functioned on the principle of sympathetic magic, attracting powerful forces to give the wearer of the charm assistance or good luck. Some of these pieces were even regarded as universally potent, like the Sacred Eye of Horus (udjat, linked to rebirth), the ankh-sign (symbolizing life) or the djed-pillar (connected with the death and resurrection of Osiris) (David 2002, 175-6). Magic was used as a solution for problems in this world (fertility magic; medicine; hostile magic from legal handling of images made out of wax or clay by priests in rites for cursing gods, men, enemies and demons; love charms; magical spells to warn off snakes) and in the world of the dead (funerary texts used in the funeral or mummification process; funerary ceremonies where the dead and mourners were linked with the archetypal divine family of Isis, Osiris, Horus and Nephtys; magic bricks) or the connection of both worlds (protective spells against returning bas and kas of the dead or to fend off the dangerous dead, called mut; Letters to the Dead as an appeal for help or accusation of evil behaviour against the living) (Pinch 2006).

We have evidence for the performance and use of magic and magical rituals in the material culture, but interestingly the artefacts (wands, corn-mummies, amulets) are not described in the formularies and magical texts. Instructions, literary descriptions of magical performances and archaeological evidence show slightly different objects (Dieleman 2008, 19, Centrone 2006, 35), so text and object do not always agree. In some cases however, we can rely on both groups of sources. Serpent wands are one example. Heka is depicted holding them in a vignette of the Book of the Dead of Nestanebtasheru (Pap. BM EA10554/88, from the Twenty-First Dynasty), suggesting that these wands had an apotropaeic connotation. Such serpent wands, made of bronze or copper alloy, have survived, such as EA52831 in the British Museum, London (Taylor 2010, 40) and E.63.1896 in the Fitzwilliam Museum, Cambridge. Both objects were part of funerary equipment: EA52831 was wrapped in the 
shroud of a mummy, found in a re-used tomb near Deir el-Bahari (Asasif). E.63.1896 was found in a late Middle Kingdom tomb (Tomb 5) of a lector priest, below the magazines of the Ramesseum at Thebes, next to a box together with the Ramesseum Papyri containing magical papyri for healing incantations, together with tales (Eloquent Peasant, Tale of Sinuhe), hymns, the Dramatic Ramesseum Papyrus, and administrative papyri (Ritner 1993, 231-2). The whole set enabled the owner of Tomb 5 to practice his profession for all eternity in the afterlife.

\section{Miniature vessels}

Miniaturization or the use of models is the application of the ancient Egyptian understanding of magic as outlined above. As such we need to comprehend that behind each of these tiny, unassuming looking vessels there lies a whole set of religious beliefs and complex philosophical thoughts. They stood for what Susan Allen called a 'sort of three-dimensional virtual reality, magically effective in the present and for eternity' (Allen 2006, 19). These miniature vessels - like all other sorts of models in the tomb, from servant figurines to the actual wall paintings - continued to provide magically for the deceased and as such nourished them in the afterlife in the same way they needed and enjoyed sustenance in this life. They were part of funerary magic, involved in ritual magic. Their inherent aspect of agency and embodiment is not yet fully researched.

Examples of miniature and model vessels in pottery and stone were given into the tomb from the early Fourth Dynasty onwards. This practice continued through the Middle Kingdom into the New Kingdom where we find innovative imitation stone vessels (Allen 2006, 19). They were also used in foundation deposits for temples and tombs. Even though there are model bowls in diverse materials, most are made from pottery (Allen 2006, 20).

Despite the sheer number in which they were found, most have been seen as some sort of novelty items, even though it was recognized that they very likely were mass produced. Despite the fact that most of them are well preserved when compared to full-size pottery sometimes even intact - they were not fully recognized as an invaluable source of 
information; maybe they were not seen to be 'the real thing', as is illustrated by the German term used for them: Scheinbeigaben - mock dishes (Martin-Pardey 1984). Egyptologists often use the terminology model and miniature interchangeably; for the ancient Egyptians however, these were two distinctive types in which size was not necessarily the defining characteristic (Allen 2006, 20). Allen understands model vessels to be objects that have votive character but with no functional capability. They could be completely solid; the important factor is the outward appearance which makes them a substitute for the real functional exemplar. We see this in the sets used in the ritual of the Opening of the Mouth which cups are usually solid and cannot be functionally used - (for example BM EA5526). Miniature vessels in contrast keep full functionality; they are simply miniaturized, smaller in scale. This vessel type appears mostly in pottery (Allen 2006, 21). Bowls like CC308.004 are difficult to imagine as models. Due to their shape and the production process of pottery, they could be functional, even though the small size would suggest an economic use, as they cannot hold a lot of their intended contents. According to the definition in the Lexikon der Ägyptologie, all Scheingaben should be seen as non-functional (Martin-Pardey 1984, 560). Both types, however, could be placed together in tombs next to full-size shapes, as evidenced in the (re-)burial of Hetepheres I in Giza (Allen 2006, 22, fig. 3). This might suggest that both models and miniatures were not seen simply as more economical substitutes, but would have had a distinctive function in the tomb.

Most model bowls are found in the context of funerary cult. These were not interred in the burial chamber, but were placed/used elsewhere in or around the tomb: the cult chapel or - in royal context - the mortuary temple. An example for the latter is a deposit of votive ceramics near the east enclosure wall of the pyramid complex for the funerary cult of pharaoh Raneferef in Abu Roash (Fourth Dynasty, see Marchand and Baud 1996, 288). Until now, the excavators have found nearly 45,000 pieces of different forms, shapes and sizes (Marchand and Baud 1996, 269), nearly 10,000 of the so-called formes ouverts, coupelles (Modellschalen, Scheinopferschälchen, model saucers, miniature bowls) comparative to CC308.004 (Marchand and Baud 1996, 272, 280, esp. figs. 6a, 9, 12b) 
Materials and matter move us: they are connected emotions and inform our sensual experiences (Boivin 2008, 106-22), both physical and symbolic or metaphysical. The previous encounters are not so different in the sphere of ancient Egyptian funerary beliefs and customs. Food and the act of offering food plays a very crucial role in the ancient Egyptian funerary beliefs as evidenced in the material culture: real foodstuffs, containers, models of food and its processing, ion images showing acquisition, production, storage and consumption of nourishment are everywhere (Ikram 2008).

\section{Materials of Funerary Offerings I: Real Food}

These miniature vessels stood for larger real dishes, which also would be given into tombs like the Middle Kingdom example from Buhen in Nubia or the New Kingdom (Eighteenth Dynasty) example from Saqqara $(16.5 \mathrm{~cm}$ and $14.6 \mathrm{~cm}$ in diameter respectively (BM EA65707; BM EA67181).They provided the same material experiences for the deceased as real vessels - filled with goods - would do for the living. What, for us, seems to be a significant difference is counterbalanced by the abstraction and spiritualization applicable for the afterlife (Martin-Pardey 1984, 560). These objects are agents of a magical-material sphere, just like the other magically enhanced objects placed in the tomb: images of offerings, reliefs offering table scenes within the false doors, statues of offering bearers and much more. In the same manner, miniature and model vessels are symbolic representatives and agents for either the implied content or the virtual act in which this vessel is meant to be incorporated.

What exactly does such an empty miniature bowl represent? We are lucky to have a very well preserved funerary meal from the burial of a Second Dynasty woman excavated by Walter B. Emery - mastaba Saqqara 3477 (Emery 1962, 6-7 for a description of the meal, pl. 6 - photos - the meal as found and reconstructed; Ikram 2008, 362-6). This full set of prepared and cooked foodstuffs was the crown jewel of this excavation, after Walter Emery had found already large quantities of foodstuffs in other early dynastic tombs of Saqqara; some evidence was discovered quite literally under the nose of the deceased as they were placed on the ground of the burial chamber to the East of the sarcophagus (Leonard 2000, 177). This evidence for funerary repast or feast, however, was too disturbed to base estimations of 
nutritional value or descriptions of food preparations on it. That changed with the find of tomb Saqqara 3477 of the Second Dynasty, a mud-brick mastaba with a niched the façade.

We can assume that the found foodstuffs are a typical festival meal of the upper class in Early Dynastic Egypt. The following courses were dished out for a meal and found well preserved and still presented on plates nearly 5000 years later:

- triangular loaf of bread (emmer wheat)

- $\quad$ porridge / cruel - made from ground barley

- cooked fish - cleaned, dressed, head removed

- pigeon stew

- a cooked quail (cleaned and dressed, head tucked under wing)

- two cooked kidneys

- ribs and legs of beef

- dish containing ribs of beef

- $\quad$ stewed fruit, probably fig

- fresh nabek berries

- small circular cakes

- small jars containing some form of cheese

- grape wine in a large jar

Interestingly, for the discussion of CC 308.004, is the fact that all offerings were served on pottery, similar in shape to our offering vessel, and not on stone vessels. Not only that, also the shape of the upper part of the offering table in the typical offering table scene depicted in one of the niches resembles the form of CC 308.004 (Emery 1962, pl. 3a).

Even we have only this one occasion of a fully preserved funerary or offering meal, certain foodstuffs were given into the tomb more regularly throughout Egyptian history. Archaeological evidence for this includes triangular bread (BM EA40942, Eleventh Dynasty), flat circular bread (BM EA5341, Middle Kingdom), figs (BM EA5368) presented 
on a real size dish, again similar in shape to our miniature bowl (BM EA45292, maybe New Kingdom) and cake (BM EA5345). The latter is circular in shape, has decorative impressions and - most interestingly - has a partially broken off edge which gives the impression as somebody has either bitten into it or broke something off. There are more examples for bones in tombs which are assumed to have been presented in containers or on dishes (Gamal-El-Din Fahmy et al. 2014, 142).

There is further evidence for cake, too - this time enclosed in a bronze case which is formed by two placed together circular dishes (MfA 13.4303, Sixth Dynasty). Such offering cases are leading to the next group of funerary offerings - models - as some of them contain real food - like MfA 13.4303 and MfA 37.552 (duck) and MfA 37.553 (pigeon) (d'Auria et al. 2000, 141-2, fig. 81a,b), but others seems to have been understood symbolically as having contained foodstuffs, even though they do not - like MfA 13.4307 which is in the shape of a joint of beef (MfA 13.4307, Eighteenth Dynasty; d'Auria et al. 2000: 93-4, fig. 26c).

\section{Materials of Funerary Offerings II: Models of Food}

Due to the understanding of death as the transition into a new phase and the hereby newly acquired abilities and level of divinity, the deceased were able to use symbolic or votive offerings and transform them magically in order to take their sustenance or satisfaction from them in much the same way as they would have used 'real things' in their worldly life.

As such, it was not necessary to provide real food in the tomb. Models of food were also seen to be sufficient, in addition to the above mentioned tangible foodstuffs. As bread and beer were the staples of ancient Egyptian food through all levels of the social hierarchy (Ikram 2001, 390; Samuel 1999a, 172), they are to be expected to be presented as models. They like all foods - were socially significant in all stages of their food provision (Samuel 1999, 123-5), both real food and symbolical representations, such as models or images. Votive offerings of bread in model form have been found in Abydos, in what the excavator Flinders Petrie described as the Abydos Temple, Altar of Khufu (maybe the Osiris temple), deposited 
in the Fourth Dynasty. One of several is a votive loaf of bread (MfA 03.1739), which is made of light red pottery and formed from a single coil of clay that has been folded over.

Again, we can find such models also in stone as the set of model offerings from the Giza mastaba G 4733 E shows (Fifth Dynasty, d'Auria et al. 2000, 93, fig. 25). In contrast to the above mentioned offering cases, which were life size, these objects are much smaller and solid. We can identify rounded cakes, meat pieces, dressed birds, vegetables, fruits and breads. One of the bread forms - the canonical one - seems to represent the bedja bread. Bedja bread moulds can be found in tombs since the Predynastic Period (d'Auria et al. 2000, 14, fig. 3) and through many periods of Egyptian history (Barta 1995, esp. 22, fig. 1). The whole set illustrates the huge variety of such models found in many tombs in Sakkara and Giza (d'Auria et al. 2000, 93).

Other models describe not the food itself, but likewise the process of making it. A good example is the model of bedja bread moulds heaped on fire (MMA 64.66.10). This model offers a glimpse into the reality of bread making - which was preserved in models like this for all eternity (for bread making as one form of food processing in ancient Egypt see also Ryan this volume; for the economic aspects connected with that see Malleson this volume). That this baking method works and could provide bread for large amounts of consumers, was proven by an experimental archaeology project run by the Ancient Egypt Research Association 1993 in Giza (AERA).

As the Egyptians aimed to establish the tomb as representation of a slightly better life in the afterlife, food which functioned as signifier of class distinction - like meat coming from domesticated animals or wild game, including also poultry and fish (Frood 2010, 484; Ikram 2001, 390) - was also included. Food offerings - so called meat mummies - were found in the funerary assemblage (Ikram 2010) and should be counted under models, even though it was real meat, as the mummified, processed substance could not be consumed. Meat - as well as models of bread, especially the model of moulds over fire - provides the conceptual link to the next section (Materials III), namely the subject of butchery models, scenes and servant figurines baking bread. 


\section{Materials of Funerary Offerings III: Symbolic Consumption after Symbolic Production}

Magical applications not only stand in for the goods - including food -used directly for the deceased in the tomb but also for the process of making these goods and thus providing a steady fresh supply for all eternity.

To exemplify the connection between real food, the model (of the object and the process) and symbolic production, I would like to start again with my example of bread (supra). Taking the model of the heaped up bread moulds further, the statuette of a female servant also illustrates an example of the agents of the production process (MfA 21.2600). In a very trueto-life manner, this woman sits in front of bread moulds stacked on the fire to bake them, her torso slightly shifted and only wearing a skirt and a piece of cloth to protect her hair from potential sparks. Even though it appears to be the representation of a single moment, like a snapshot, the actual provision of this statue in the tomb means the action is symbolically happening for all eternity. These representations are called serving or servant statues, however, she could equally have been a servant or a member of the family of the deceased, as some of the inscribed statues suggest (Roth 2002).

In the tomb of Intef (TT 155; Säve-Söderbergh 1957, 18, pl. 15), we see the depiction of a private wine cellar from his estate. Having the wine cellar - and depictions of the production process of the wine - represented in the tomb, guaranteed a steady influx of wine for all eternity. Wine was consumed during the funerary banquets, as depicted in the tombs (Poo $1995,28)$ - maybe even in excess as is seen in some tombs when drunken guests need to be supported. Banquet scenes are one of the best well-known decorative motifs in New Kingdom elite tombs (Harrington 2015). The excessive drinking is evidenced in Theban tombs like Senna (TT 169, Eighteenth Dynasty, reign of Amenhotep II), where a drunken guest needs to be carried away by others during the banquet (Murray et al. 2000, 578, fig. 23.3), or in the tomb of Neferhotep (TT49, Eighteenth Dynasty, reign of Tutankhamun), where a woman needs to be supported by a female servant while vomiting (Bryan 2014, 11516, fig. 6.31). A similar scene is depicted in the painted plaster from an unknown tomb showing a man vomiting into the lap of his neighbour (Brussels E.2877). This might be connected with the participatory Festival of Drunkenness (Bryan 2014), which seems to be 
celebrated in temples and shrines at least since the Eighteenth dynasty (co-regency of Hatshepsut and Thutmosis III), inspired by the myth of The Heavenly Cow where making Hathor drunk would save mankind of her rage (Guilhou 2010). Being drunk is often connected with getting into an altered state, communal ritual activity and so to connect with the divine (see also Steel and Collard this volume): inebriation was a means to access or communicate with divine beings (Bryan 2014, 107, 115), also possibly including the now altered deceased. Drunkenness is also connected with sexual behaviour (Bryan 2014, 118120), which brings us back to the idea of regeneration and rebirth. This is supported by texts from Edfu showing a relationship between the production of wine and the inundation (Poo $2010,2)$. This is not only a symbolic act of feasting and celebration as interaction between the deceased and this world. We have evidence for actual banquets in the tombs. Even the banquets scenes can be found in the longitudinal hall, the actual place for banquets would have been in the courtyard (Harrington 2015, 12-16).

A related attitude of 'make merry' (Lichtheim 1945, 181) becomes clear from texts belonging to the genre of the so-called Harpers' Songs and often accompanying banquet scenes or the depiction of the deceased before the offering table. In the tomb of User (TT 21, Eighteenth Dynasty, reign of Thutmosis I) a daughter presents a cup before the deceased couple sitting at the offering table and says: 'For thy Ka! Drink, be happily drunk, and make holiday! ... Thou shalt never cease to enjoy thyself within thy beautiful home.' (Lichtheim 1945, 183) The idea of living on in the tomb as a good time is still mentioned at the end of the Egyptian history, so in the stela of Tjaiemhotep (BM EA147, translation: Lichtheim 1980, 62-3) ${ }^{3}$ :

Weary not of drink and food,

Of drinking deep and loving!

Celebrate the holiday,

Follow your heart day and night,

Let not care into your heart,

Value the years spent on earth!

Such scenes and the Harpers' Songs offer a different take on eating / banqueting etiquettes mentioned in the Teachings addressed to scribes and members of the administrative elite, communicating the right behaviour to superiors: (Lichtheim 1975, 59-60) 
When you sit with company,

Shun the food you love;

Restraint is a brief moment,

Gluttony is base and is reproved.

The vessels, participants of funerary banquets used to drink from as seen in the banquet scenes, are similar in shape to our miniature dish. In addition to the above mentioned scenes, this can also be seen in the scene from the Theban tomb of the vizier Rekhmire - TT100 where serving girls pour the female guests of Rekhmire's funeral - among them Rekhmire's mother Bet - wine (Osirisnet Rekhmire I; Osirisnet Rekhmire II; TT110: Longitudinal Hall, North Wall). In these cases we obviously see the full size drinking vessels and not the miniature examples, as comparison with the hands holding the vessels makes clear.

The most extreme metaphoric versions of (symbolic) materiality are represented by offering lists. More extensive are the list of festival offerings in temples, which might have been similar to lists for royal funerary festivals. They name wine, water, several kinds of bread, fruits, vegetables and especially a variety of meat (for meat see Ikram 1995). Such lists are important to take into consideration as they express real offerings used in rituals and festivities in contrast to the offering lists written on the false doors in private tombs which state an ideal (Sayed Mohamed 2004, 132).

\section{THE (PRELIMINARY) CONCLUSION: LACKLUSTRE, BUT INTERESTING?}

What does all this mean for our lacklustre mass-produced dish? Were there ever fruits or meat chunks placed on it? Did the $k a$ rise and move the dish to its mouth in order to get drunk? Can we even determine a certain Sitz im Leben (or death as it is more likely in our case)? No, but these are not the main problems anyway. This little vessel could have done all this, it could have been used to embody whatever was symbolically and magically meant to be on it or what was associated with it. Therefore it stands as a marker for foodstuffs, food consumption, consumed sustenance and explains an important part of ancient Egyptian afterlife beliefs. To understand the ambivalence between actual and symbolic food consumption and the expression of both in the materiality of the object was the goal of this 
extended object biography. What is of greater interest is the link between the narrative of the object, foodstuffs and the connected social worlds that it represents (Steel 2013, esp. 190-6). What has been presented here is a narrative of realistic and potential life cycle and the biography of a single lacklustre object CC308.004 with its incredible interesting storyline. 


\section{REFERENCES}

AERA (2015) Feeding pyramid workers .Ancient Egyptian Research Associates. Online. Available HTTP: <http://www.aeraweb.org/lost-city-project/feeding-pyramidworkers/> (accessed February 2016).

Arnold, D. \& J. Bourriau (eds.) (1993) An Introduction to Ancient Egyptian Pottery II: Ceramic Technology: Clays and Fabrics. Mainz: Zabern.

Allen, S. (2006) 'Miniature and model vessels in Ancient Egypt', in M. Barta (ed.) The Old Kingdom Art and Archaeology: Proceedings of the Conference held in Prague, May 31 - June 4, 2004, 19-24. Prague: Academia.

Allen, T.G. (1974) The Book of the Dead or Going Forth by Day: Ideas of the Ancient Egyptians Concerning the Hereafter as Expressed in Their Own Terms. Chicago, IL: Oriental Institute.

Assmann, J. (2005) Death and Salvation in Ancient Egypt. Ithaca, NY: Cornell University Press.

Baines, J. (2006) 'Display of magic in Old Kingdom Egypt', in K. Szpakowska (ed.) Through a Glass Darkly: Magic, Dreams, and Prophecy in Ancient Egypt: 1-32. Swansea: Classical Press of Wales.

Barta, M. (1995) 'Archaeology and iconography: bd 3 and prt bread moulds and 'Speisetischszene' development in the Old Kingdom', Studien zur Altägyptischen Kultur 22: 21-35.

BM 1888,0601.735.b (nd.) 'Votive offering / bowl', British Museum. Online. Available HTTP:

$<$ http://www.britishmuseum.org/research/collection_online/collection_object_details. aspx objectId=3473357\&partId=1\&searchText=1888\%2c0601.735.b\&page=1> (accessed February 2016).

BM EA147 (nd.) 'Stela’, British Museum. Online. Available HTTP: $<$ http://www.britishmuseum.org/research/collection_online/collection_object_details. aspx? objectId $=111515 \&$ partId $=1 \&$ searchText=ea $+147 \&$ page $=1>($ accessed February 2016).

BM EA40942 (nd.) 'Food product', British Museum. Online. Available HTTP: $<$ http://www.britishmuseum.org/research/collection_online/collection_object_details. 


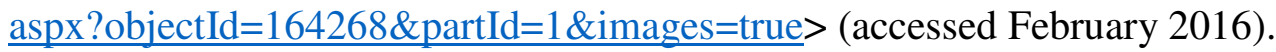

BM EA45292 (nd.) 'Dish', British Museum. Online. Available HTTP:

$<$ http://www.britishmuseum.org/research/collection_online/collection_object_details. aspx?objectId=118656\&partId=1\&searchText=dish+figs\&page $=1>($ accessed February 2016).

BM EA5341 (nd.) 'Food product/dish’ British Museum. Online. Available HTTP: $<$ http://www.britishmuseum.org/research/collection_online/collection_object_details. aspx ?objectId=118665\&partId=1\&searchText=bread+Egypt\&images=true \&page $=1>$ (accessed February 2016).

BM EA5345 (nd.) 'Food product', British Museum. Online. Available HTTP:

$<\underline{\text { http://www.britishmuseum.org/research/collection_online/collection_object_details. }}$ aspx?objectId=176843\&partId=1\&searchText=bread+Egypt\&images=true\&page=1> (accessed February 2016).

BM EA5368 (nd.) 'Vegetal remains', British Museum. Online. Available HTTP:

$<$ http://www.britishmuseum.org/research/collection_online/collection_object_details. aspx ?objectId=118655\&partId=1\&searchText=5368\&page $=1>($ accessed February 2016).

BM EA5526 (nd.) 'Vessel/tool/implement; religious/ritual equipment/model', British Museum. Online Available HTTP:

$<$ http://www.britishmuseum.org/research/collection_online/collection_object_details. aspx ?objectId=117463\&partId=1\&searchText=5526\&page $=1>($ accessed February 2016).

BM EA64088 (nd.) 'Offering-bowl/model/foundation-deposit', British Museum. Online. Available HTTP:

$<$ http://www.britishmuseum.org/research/collection_online/collection_object_details. $\underline{\text { aspx }}$ objectId=116311\&partId=1\&searchText=offering+Egypt\&images=true $\&$ page $=$ $1>$ (accessed February 2016).

BM EA65707 (nd.) 'Dish', British Museum. Online. Available HTTP:

$<$ http://www.britishmuseum.org/research/collection_online/collection_object_details. aspx?objectId=116428\&partId=1\&searchText=dish+Egypt\&images=true\&page=1> (accessed February 2016). 
BM EA67181 (nd.) 'Dish', British Museum. Online. Available HTTP:

$<$ http://www.britishmuseum.org/research/collection_online/collection_object_details. $\underline{\text { aspx }}$ ?objectId=116350\&partId=1\&searchText=dish+Egypt\&images=true \&page=1> (accessed February 2016).

BM EA67299 (nd.) 'Model/dish', British Museum. Online. Available HTTP:

$<\underline{\text { http://www.britishmuseum.org/research/collection_online/collection_object_details. }}$ aspx ?objectId=119700\&partId=1\&searchText=dish+Egypt\&images=true \&page=1> (accessed February 2016).

Boivin, C. (2008) Material Cultures, Material Minds: The Impact of Things on Human Thought, Society, and Evolution, Cambridge: Cambridge University Press.

Bourriau, J.D., P.T. Nicholson \&P.J. Rose (2000) 'Pottery', in Nicholson, P.T \& I. Shaw (eds.). Ancient Egyptian Materials and Technologies. 121-147. Cambridge: Cambridge University Press.

Brussels E.2877 (nd.) Banquet scene. Online. Available HTTP: $<$ http://www.globalegyptianmuseum.org/detail.aspx?id=450 $>$ (accessed February 2016).

Bryan, B.M. (2014) 'Hatshepsut and cultic revelries in the New Kingdom', in J.M. Galán; B.M. Bryan \& P.F. Dorman (eds) Creativity and Innovation in the Reign of Hatshepsut. Occasional Papers of the Theban Workshop 2010, 93-125. Chicago: Oriental Institute.

Centrone, M (2006) 'Corn-mummies, amulets of life', in K. Szpakowska (ed.) Through a Glass Darkly: Magic, Dreams, and Prophecy in Ancient Egypt, 33-45. Swansea: Classical Press of Wales.

d'Auria, S., P. Lacovara \& C. Roehrig (2000) Mummies \& Magic: The Funerary Arts of Ancient Egypt, Boston: Museum of Fine Arts.

David, R. (2002) Religion and Magic in Ancient Egypt, London: Penguin.

Davies, D. (1994) 'Introduction: raising the issues', in J. Holm (ed.) Rites of Passage, 1-9. London: Pinter.

Dieleman, J. (2008) 'Review: Through a Glass Darkly: Magic, Dreams, and Prophecy in Ancient Egypt, edited by K. Szpakowska', Aestimatio 5: 15-22. 
Emery, W.B. (1962) A Funerary Repast in an Egyptian Tomb of the Archaic Period, Leiden: Nederlands Instituut voor het Nabije Oosten.

Faulkner, R. \& C. Andrews (1998) The Egyptian Book of the Dead: The Book of Going Forth By Day, San Francisco, CA: Chronicle Books.

Frood, E. (2010) 'Social structure and daily life: Pharaonic', in A. Lloyd (ed.), A Companion to Ancient Egypt I, 469-90. Oxford: Wiley-Blackwell.

Gamal-El-Din Fahmy, A., N. Kawai \& S. Yoshimura (2014) 'Archaeobotany of two Middle Kingdom cult chambers at Northwest Saqqara, Egypt', in C.J. Stevens, S. Nixon, M.A. Murray \& D.Q. Fuller (eds) Archaeology of African Plant Use, 141-9. Walnut Creek, CA: Left Coast Press.

Guilhou, N. (2010) 'Myth of the heavenly cow', in J. Dieleman \& W. Wendrich (eds) UCLA Encyclopedia of Egyptology. Online. Available HTTP: <http://digital2.library.ucla.edu/viewItem.do?ark=21198/zz002311pm> (accessed February 2016).

Harrington, N. (2013) Living with the Dead: Ancestor Worship and Mortuary Ritual in Ancient Egypt, Oxford: Oxbow. (2015, forthcoming) 'The Eighteenth Dynasty Egyptian banquet: ideals and realities', in C.M. Draycott \& M. Stamatopoulou (eds) Dining and Death: Interdisciplinary Perspectives on the "Funerary Banquet" in Art, Burial and Belief. Leuven: Peeters. Online. Available HTTP: < https://www.academia.edu/1393462/The_Eighteenth_Dynasty_Egyptian_banquet_id eals_and_realities $>$ (accessed February 2016).

Hayes, W. (1978) The Scepter of Egypt: A Background for the Study of the Egyptian Antiquities in The Metropolitan Museum of Art. Vol. 1, From the Earliest Times to the End of the Middle Kingdom, New York, NY: Metropolitan Museum of Art.

Ikram, S. (1995) Choice Cuts: Meat Production in Ancient Egypt, Leuven: Peeters. (2001) 'Diet', in D.B. Redford (ed.) The Oxford Encyclopedia of Ancient Egypt I, 390-5. Oxford: Oxford University Press. (2008) 'Food and funerals. Sustaining the dead for eternity', Polish Archaeology in the Mediterranean (PAM) 20: 361-71. 
(2010) 'Victual, ritual or both? Food offerings from the funerary assemblage of

Isitemkhet', Studi die Egittologia e di Papirologia: Rivista Internazionale 1: 87-92.

Kucharek, A. (2005) '70 Tage - Trauerphasen und Trauerriten in Ägypten', in J. Assmann, F. Maciejewski \& A. Michaels (eds.) Der Abschied von den Toten: Trauerrituale im Kulturvergleich. 342-58. Göttingen: Wallstein Verlag.

Leonard, A. (2000) 'Food for thought: Saqqara Tomb 3477 revisited', Near Eastern Archaeology 63(3): 177-9.

Lichtheim, M. (1945) 'The Songs of the Harpers', Journal of Near Eastern Studies 4(3): 178212.

(1975) Ancient Egyptian Literature - A Book of Readings I: The Old and Middle Kingdoms, Berkeley, CA: University of California Press.

(1980) Ancient Egyptian Literature - A Book of Readings III: The Late Period.

Berkeley, CA: University of California Press.

Martin-Pardey, E. (1984) ‘Scheinbeigaben’ Lexikon der Ägyptologie V: 560-3.

Marchand, S. \& M. Baud (1996) 'La céramique miniature d'Abou Rawash. Un dépôt à l'entrée des enclos orientaux', Bulletin de l'Institut Français d'Archéologie Orientale 96: $255-88$

MfA 03.1739 (2016) 'Votive loaf of bread', Museum of Fine Arts, Boston. Online. Available HTTP: <http://www.mfa.org/collections/object/votive-loaf-of-bread-130672> (accessed February 2016).

MfA 05.62 (2016) 'Model bowl from foundation deposit of Hatshepsut', Museum of Fine Arts, Boston. Online. Available HTTP:

$<$ http://www.mfa.org/collections/object/model-bowl-from-foundation-deposit-ofhatshepsut-132656> (accessed February 2016).

MfA 13.4303 (2016) 'Food case with bread', Museum of Fine Arts, Boston. Online. Available HTTP: <http://educators.mfa.org/ancient/food-case-bread-56436> (accessed February 2016).

MfA 13.4307 (2002-2016) 'Offering case in the shape of a joint of beef (lower part)', Metropolitan Museum of Art, New York. Online. Available HTTP: $<$ http://educators.mfa.org/ancient/offering-case-shape-joint-beef-lower-part-56456> 
(accessed February 2016).

MMA 13.183.185 (2000-2016) Miniature vessel from Tomb of Perneb. Metropolitan Museum of Art, New York. Online. Available HTTP:

<http://www.metmuseum.org/collection/the-collection-online/search/547064> (accessed February 2016).

MMA 13.183.187 (2000-2016) 'Miniature vessel from Tomb of Perneb', Metropolitan Museum of Art, New York. Online. Available HTTP:

$<$ <ttp://www.metmuseum.org/collection/the-collection-online/search/547066> (accessed February 2016).

MMA 13.183.189 (2000-2016) 'Miniature vessel from Tomb of Perneb', Metropolitan Museum of Art, New York. Online. Available HTTP:

<http://www.metmuseum.org/collection/the-collection-online/search/547068> (accessed February 2016).

MMA 13.183.190 (2000-2016) 'Miniature vessel from Tomb of Perneb', Metropolitan Museum of Art, New York. Online. Available HTTP:

<http://www.metmuseum.org/collection/the-collection-online/search/547069> (accessed February 2016).

MMA 19.2.16 (2000-2016)' Libation dish depicting ka-arms presenting an ankh-sign', Available at $<$ http://www.metmuseum.org/art/collection/search/543866 $>$ (accessed February 2016).

Murray, M.A., N. Boulton \& C. Heron (2000) 'Viticulture and wine production', in P.T Nicholson \& I. Shaw, I. (eds.) Ancient Egyptian Materials and Technologies, 577608. Cambridge: Cambridge University Press.

Osirisnet Ameneminet (nd.) Ameneminet. Online. Available HTTP: <http://www.osirisnet.net/popupImage.php?img=/tombes/nobles/ameneminet277/phot o/ameneminet277_bs_unidia_39351.jpg \&sw=1680\&sh=1050\&wo=0\&so=85> (accessed February 2016).

Osirisnet Rekhmire I (nd.) Rekhmire I. Online. Available HTTP:

<http://www.osirisnet.net/popupImage.php?img=/tombes/nobles/rekhmire100/photo/r ekhmire_tt100_cm_638.jpg\&sw=1366\&sh=768\&wo=0\&so=85> (accessed February 2016). 
Osirisnet Rekhmire II (nd.) Rekhmire II. Online. Available HTTP:

<http://www.osirisnet.net/popupImage.php?img=/tombes/nobles/rekhmire100/photo/r ekhmire_tt100_sh_420.jpg\&sw=1366\&sh=768\&wo=0\&so=85> (accessed February 2016).

Pinch, G. (2006) Magic in Ancient Egypt, London: British Museum Press.

Poo, M.-C. (1995) Wine and Wine Offering in the Religion of Ancient Egypt, London: Kegan Paul International. (2010) 'Liquids in Temple Ritual', in J. Dieleman \& W. Wendrich (eds), UCLA Encyclopedia of Egyptology. Online. Available HTTP: <http://escholarship.org/uc/item/7gh1n151> (accessed February 2016).

Richards, J. (2005) Society and Death in Ancient Egypt: Mortuary Landscapes of the Middle Kingdom, Cambridge: Cambridge University Press.

Ritner, R. K. (1992) 'Egyptian Magic: Questions of Legitimacy, Religious Orthodoxy and Social Deviance', in A. B. Lloyd (ed.) Studies in Pharaonic Religion and Society in Honour of J. Gwyn Griffiths, 189-200. London: Egypt Exploration Society. (1993) The Mechanics of Ancient Egyptian Magical Practice. Chicago: Oriental Institute. (2001) 'Magic: An Overview', in D.B. Redford (ed.) The Oxford Encyclopedia of Ancient Egypt II, 321-6. Oxford: Oxford University Press.

Roth, A.M. (2002) 'The Meaning of Menial Labor: "Servant Statues" in Old Kingdom Serdabs', Journal of the American Research Center in Egypt 39: 103-121.

Samuel, D. (1999) 'Bread Making and Social Interactions at the Amarna Workmen's Village, Egypt'. World Archaeology 31(1): 121-44.

(1999a) 'Brewing and Baking in Ancient Egyptian Art', in H. Walker (ed.) Food in the Arts. Proceedings of the Oxford Symposium on Food and Cookery, 173-81.

Totnes: Prospect Books. (2006) 'Archaeology of Food', in A. Davidson (ed.) The Oxford Companion to Food. $2^{\text {nd }}$ ed. 33-4. Oxford: Oxford University Press.

Säve-Söderbergh, T. (1957) Four $18^{\text {th }}$ Dynasty Tombs, Oxford: Oxford University Press. Sayed Mohamed, Z. (2004) Festvorbereitungen: Die administrativen und ökonomischen 
Grundlagen altägyptischer Feste, Fribourg: Academic Press.

Steel, L. (2013) Materiality and Consumption in the Bronze Age Mediterranean, New York, NY, London: Routledge.

Taylor, J. (2001) Death and the Afterlife in Ancient Egypt, London: British Museum Press. (2010) Journey through the afterlife: The Ancient Egyptian Book of the Dead, London: Harvard University Press.

Te Velde, H. (1967) Seth, God of Confusion, Leiden: Brill. (1970) 'The God Heka in Egyptian Theology', Jaarbericht van het VoorasiatischEgyptisch Genootschap Ex Oriente Lux 21: 175-87.

van Gennep, A. (1909) Les Rites de Passage; trans. M.B. Vizedom \& G.L. Caffee (1960) The Rites of Passage, Chicago, IL: University of Chicago Press.

Weinstein, J.A. (2001) 'Foundation Deposits', in D.B. Redford (ed.) The Oxford Encyclopedia of Ancient Egypt I, 559-61. Oxford: Oxford University Press.

Wilkinson, R.H. (2003) The Complete Gods and Goddesses of Ancient Egypt,London: Thames and Hudson.

Wodzińska, A. (2010) A Manual of Egyptian Pottery 1: Fayum A-Lower Egyptian Culture. Rev. edn. Boston, MA: Ancient Egypt Research Associates.

Yeoh. B.S.A. (1999) 'The body after death: place, tradition and the nation state in Singapore', in E.K. Teather (ed.) Embodied Geographies: Spaces, Bodies and Rites of Passage, 241-55. London: Routledge.

Zinn, K. (2013) 'Magic, Pharaonic Egypt', in R.S. Bagnal, K. Brodersen, C.B. Champion, A. Erskine \& S.R. Huebner (eds) The Encyclopedia of Ancient History, 4227-31. Oxford: Blackwell. 


\section{NOTES}

${ }^{1}$ This study is part of a wider project looking at 'secondary archaeology' of long-forgotten exotic objects brought back from faraway places in the nineteenth century as part of imperial exploration and which now reside in community museums. The focus is a group of ancient Egyptian objects now in the Cyfarthfa Castle Museum, which were collected in Egypt early in the twentieth century by Harry Hartley Southey (1871-1917), son of a local Welsh newspaper, whilst stationed in Egypt. Many thanks go to the staff of Cyfarthfa Castle Museum, especially Kelly Powell and Michelle Lewis.

${ }^{2}$ This passage is differently translated. The here given one goes back to the translation by Budge, other translations are not so clear: Faulkner speaks in a non-literal translation of " $[\mathrm{H}] \mathrm{e}$ [i.e. Thoth] it was who helped you, O Osiris, on that night of death" (Faulkner, Andrews 1998: 128). Allen follows more literally: "It was Osiris who made (it) for him that night of proceeding to life (i.e. dying)" (Allen 1974: 178).

${ }^{3}$ For an alternative translation see (BM EA147): 'Do not [be] weary of drinking, eating, getting intoxicated and making love! Make holiday! Follow your heart day and night! Let not care into your heart otherwise what use are your years upon earth? As for the west, it is a land of sleep; darkness weighs on that place where the dead dwell. Sleeping as mummies they do not wake to see their brothers, they are not conscious of fathers or mothers, their hearts forget their children. The water of life which is nourishment for all is thirst for me: it only comes forth to those upon earth'. 